\section{When enough is not enough}

\section{Howard Rush, Pauline Marstrand, John Gribbin and Gordon Mac- Kerron look at what is sometimes called the world food paradox}

WITHIN the past few months a series of publications* has again focused attention on the complex of problems underlying the "world food crisis". These analyses aim at different audiences, but all have a message in common: our inability to feed the world's population is not due to physical factors placing limitations on total world food production. They also recognise that the causal factors in world hunger and malnutrition are the enormous economic, social and political problems associated with poverty.

The key physical factor, of course, is availability of land. Most recent estimates are based on calculations published in 1967 by the US President's Science Advisory Committee (PSAC), suggesting that the maximum area which would be cropped is 6,600 million hectares, of which about half has been cultivated at some time and about 1,400 million hectares harvested in any one year. Although other estimatessuch as those by FAO and the US Department of Agriculture-have produced a broad spread of figures, the PSAC estimates are roughly in the middle of the range, and all investigators agree that only about half of the potential area is now used. The estimates differ partly because of different assumptions about the feasibility of obtaining water, but they all show that apart from competing uses of land, existing world food production could be roughly doubled without improved technology.

Lester Brown and others have postulated that increasing costs of development will preclude utilisation of much of this land-an assumntion also built into the Limits to Growth modelbut there is room to querv this assumption. Although it is true that the tendency is for the range of available technologies to move towards the very capital intensive (and expensive) end of the spectrum, in principle developing countries can still select from alternatives ranging down to such labour intensive proiects as the human muscle used to build the Yangtse dam. There is certainly room here for further

*Future World Trends, UK Cabinet Office (April 1976): The World Food Crisis and Third World Development: Implications for UK Policy. UK Select Committee on Overseas Development (February 1976); Profits of Doom, C. Robbins and Javed Ansair (War on Want, January 1976); World Food: A Political Task, Howard Wagstaff (Fabian Research Series 326).

The authors are all at the Science Policy Research Unit, University of Sussex. debate, partly because future cost assumptions depend so heavily on the nature and pace of future technological change.

Using the PSAC estimates, the maximum population supportable has been taken as 7,200 million at existing standards of nutrition, or 157,000 million on a 1967 "Japanese" diet. Although it is commonly stated that 400-500 million people are starving in the world today, it seems unlikely on the basis of WHO estimates that more than 60-70 million are currently so severely undernourished that they are using bodily protein reserves (muscles, including heart muscle) as a source of metabolic energy.

\section{The important factors}

This represents less than $2 \%$ of the present world population, and is probably a smaller proportion than ever before, but it is nothing to be proud of; the efforts made over the past three decades to improve food supply to the hungry have beeen successful in part and are worth sustaining. But if physical factors are not critical in determining the availability of food to the world's population now and in the immediate future, what are the important factors-and are they really so enormous as to provide insurmountable difficulties?

The key to the world food "problem" is now seen to be poverty, not population. Poverty within nations means that poor people receive a smaller share of the food available nationally, while poverty between nations means that the poorer nations have less food per head to share in the first place. And the inequalities are greatest in the poorest rations, so that the smallest slices of the cake are themselves divided the most unfairly.

Between 1951 and 1971 the global production of cereals more than doubled, while the world's population "only" increased by $50 \%$. More than half of the increase in food, however, was absorbed by the richest $30 \%$ of mankind, so that the extra food was shared almost equally between 1,000 million people in the developed countries (DCs) and the 2,500 million people in the less developed countries (LDCs). This pattern emphasises that the food is there-or can be produced-for those who can afford it. It is because they are poor that the hungry-whether they be nations or individuals-are unable to buy sufficient food, or to develop their farming sufficiently to provide for their own needs. Under the present world economic system, their hunger, as such, is largely irrelevant; "demand", in the food market as in other markets, means ability (or willingness) to pay. As in other free markets, the rich have a dominant influence: their power in the market distorts demand patterns, and allows them to obtain the greatest benefits for themselves. One important result is that in the poor nations-as well as the rich-increasing demand for meat prevents the most effective use of available land by diverting large areas of cereal from human to (inefficient) animal consumption.

It was a reduction in this market demand that led to a reduction in planted cereal acreage in the developed countries during the $1960 \mathrm{~s}$, at a time when there was clearly an increasing need for food among the hungry poor who had no financial access to, or influence on, the market. Between 1960 and 1970 the LDCs were increasing food production at least as fast as the developed countries, but the increasing market demand for "luxury" foodbeef, dairy produce and so on-forced prices upwards, including the prices of cereals used for feeding animals as well as people. Together with the emphasis at government level in many LDCs on cash crops that could be sold to developed countries to boost exports (coffee, sugar and so on) this had serious effects on the poor in the LDCs, where even if luxury foods were being exported essential foods had still to be imported in bulk (as represented in Table 1).

The shortages of the early 1970 s and high prices have been blamed on many natural factors, not least the weather

\begin{tabular}{|c|c|c|c|c|c|}
\hline Region & $1934-38$ & $1948-52$ & 1960 & 1966 & $1973^{*}$ \\
\hline $\begin{array}{l}\text { North America } \\
\text { Latin America } \\
\text { West Europe } \\
\text { East Europe \& USSR } \\
\text { Africa } \\
\text { Asia } \\
\text { Australia, New Zealand }\end{array}$ & $\begin{array}{l}+5 \\
+9 \\
+24 \\
+5 \\
+1 \\
+2 \\
+3\end{array}$ & $\begin{array}{l}+23 \\
+1 \\
-22 \\
* * \\
0 \\
-6 \\
+3\end{array}$ & $\begin{array}{l}+39 \\
* * \\
-25 \\
0 \\
-2 \\
-17 \\
+6\end{array}$ & $\begin{array}{l}+59 \\
+5 \\
+5 \\
-4 \\
-7 \\
-34 \\
+8\end{array}$ & $\begin{array}{l}+91 \\
-3 \\
-3 \\
-27 \\
-5 \\
-43 \\
+6\end{array}$ \\
\hline
\end{tabular}

Plus sign indicates net exports; minus sign net imports

Plus sign indicates net exports;
*Estimated **Not available

Source: Financial Times 
(which, in fact, was not so much bad as simply worse than the previous, exceptionally good, years of the 1960s). But these shortages, although real, were not physically necessary; they resulted from the control of the market by producers in the developed countries.

LDCs can only pay for the food they import with the foreign exchange earned by their exports; ironically, agricultural produce makes up threequarters of those exports, but the LDCs' share of the world market in these products is falling as the developed countries produce more and increase their domination of the market. According to War on Want, "In 1966 , prices for exports from the DCs were $13 \%$ higher than in 1958 while prices for exports from the LDCs fell by $11 \% \ldots$ more and more has to be exported to buy the same goods from the DCs". The resulting imbalance, with the developing nations' debts to foreign countries increasing substantially faster than their GNP, means that in the majority of cases the gap between debts contracted and the means of repaying them is widening every year. As this gap increases so do the inequalities between developed and developing nations.

\section{Internal factors}

The responsibility for this, however, does not lie solely with the developed nations' control over world markets. Their market control does place the poor of developing nations at a severe disadvantage, but the inequalities are heavily reinforced by agricultural policies and local price factors within the developing nations themselves, where agriculture accounts for more than a third of total production and rural regions provide about threequarters of the total population.

These regions and most of their impoverished population have little say or control over their economy. The majority are landless or own less than a single hectare of land. What little agricultural policy there is in many L.DCs, including investment programmes, is heavily biased in favour of the prosperous minority. The result of this imbalance is clearly seen in the example of India, where $7.7 \%$ of the population own more than $50 \%$ of the head. More often than not the situation is made worse by national development policies which stress industrialisation of urban areas dependent on the agricultural sector for resources.

As Keith Griffin has pointed out, the outstanding feature of the agricultural sector in almost all LDCs is the bias in access to factors of production (that is, land, credit, water, fertilizers, technical knowledge, etc.) towards the prosperous landowners. Government policies supported by the economic and political influence of this minority virtually control the market structure and allocation of resources-thus assuring no shift in the status quo detrimental to their interests.

Technical change, once heralded in the form of the "green revolution" as the solution to man's hunger, becomes a further aid to the rich because of their dominance of the world system. Technical change which relies on easy access to credit and often substantial inputs of water, fertilizer and pesticides, may well increase production-but only for the minority of landowers in whose favour the market is biased. Any innovation under the control of the status quo tends to strengthen the status quo. Agricultural innovation has become widespread, but the result has not only been increases in productivity but also increases in inequality; the rich get richer, but the poor get poorer.

In recent years the world's food supply has increased faster than the rate of population growth. As suggested by nearly all recent analysis, physical factors are not critical to feeding the world's population. But the fact that fewer people need face starvation than previously believed does not reduce the seriousness of the difficulties which remain: the problems are now recognised as those of poverty and politics. It might seem that these are no less insurmountable than the physical restrictions often assumed-although we could feed a much larger population, it may require a social revolution to remove the inequalities at the root of poverty. As the UK Select Committee on Overseas Development stressed in its report, "the main answer to the world food problem is to give those who are hungry the means to feed themselves, or the income to buy food".

\section{Antidisestablishmentarianism}

Arrangements by which the US President receives advice on science matters have now been institutionalised. Colin Norman reports from Washington.

WITH storm clouds hovering overhead, and with many elder statesmen of the scientific community in attendance, President Ford last week held a small ceremony in the White House rose garden to mark the signing into law of a bill re-establishing a science policy office in the White House.

The event was pure ceremony. Contrary to rumours flying around beforehand, $\mathrm{Mr}$ Ford did not nominate anybody to head the office-the director will also be the President's Science Adviser-nor did he indicate how he intends to use the office when it is eventually set up. Instead, he simply took the opportunity to make a fcw obligatory remarks about the importance of science and technology in helping to meet "the challenges and opportunities which lie ahead for this nation and the world", and signed the bill with "great pleasure". Fortunately, the rain held off.

The ceremony nevertheless marked an important event in the annals of science policy. The bill, which had been championed by numerous prominent scientists and also by Vice-President Nelson Rockefeller, essentially reinstates the science policy apparatus dismantled three years ago by $\mathrm{Mr}$ Nixon. Moreover, since the office has now been established by an Act of Congress-rather than an act of Presidential pique--to remove it.

Though scientists, of course, played a prominent role in shaping national policy during the Second World War, they didn't have a permanent place in the White House until 1957, when President Eisenhower acquired a fulltime science adviser during the postSputnik panic which swept the

\section{Sorry, for copyright reasons some images on this page may not be available online}

President Ford signs the science policy bill, watched by (left) Senator Frank Moss, chairman of the Senate Space Committee, and Representative Olin Teague, chairman of the House Committee on Science and Technology.

country. The adviser was made chairman of the President's Science Advisory Committee, a panel of scientists drawn from academie and industry. President Kennedy established the Office of Science and Technology (OST) 